\title{
A "Vênus negra": Josephine Baker e a modernidade afro-atlântica
}

\section{The "Black Venus": Josephine Baker and afro-Atlantic modernity}

Petrônio Domingues

Ó bizarra deidade, escura como os lutos, De perfume que junta almíscar mais havana, Obra de algum obi, o Fausto da savana, Sombria feiticeira, a dos negros minutos

“Sed non satiata", Charles Baudelaire (2001:39).

No dia 13 de janeiro de 1929, o jornal da imprensa negra Progresso, de São Paulo, publicava uma reportagem para celebrar as conquistas que a multiartista afro-americana Josephine Baker vinha obtendo no show business do Velho

Petrônio Domingues é doutor em História pela Universidade de São Paulo e professor da Universidade Federal de Sergipe, Aracaju, Brasil (pjdomingues@yahoo.com.br).

Artigo recebido em 30 de dezembro de 2009 e aprovado para publicação em 8 de abril de 2010. 
Continente. Intitulada "a musa negra e os seus triunfos na Europa", a reportagem informava que Baker "continua a resplandecer no cenário internacional e a acrescentar diariamente uma fortuna que anda em alturas de milhões". Quando se apresentou no palco parisiense, "tudo lhe correu pelo melhor". O motivo do sucesso daquela negra norte-americana era explicado na reportagem. Como o público europeu estava habituado a um modelo tradicional da "arte ligeira, tão tradicional que vai atingindo a monotonia", sentiu-se "deslumbrado" perante uma "criatura exótica; trepidante, diabólica na sem-cerimônia da sua comicidade" e, ademais, "perturbadora na graça escultural do seu corpo de ébano. O público não limitou as expressões de seu entusiasmo e a 'Vênus ${ }^{1}$ Negra' teve um triunfo como desde muito não se verificava em Paris". A reportagem continuava a destacar suas façanhas na Europa:

Os próprios profissionais da arte ligeira não a hostilizaram do primeiro momento, seduzidos pela originalidade dessa jovem de vinte anos, que se apresentava tão fora de todos os moldes e que lhes permitia, através da viva crítica que era dos povos novos aquilatarem e estimarem o lustre, a linha, a medida elegante da sua antiga consagrada civilização. Mas Josephine, ritmando os seus passos toscos, mesmo bárbaros, ganhava demasiado o favor do público e dinheiro. Seu nome fazia-se uma centelha maravilhosa, que aliciava meio mundo, e essa gente, a princípio risonha, começou a afligir-se com tão ruidoso e prolongado êxito. Veio a intriga. Veio a perfídia. Vieram as cartas anônimas, os insultos, e a Baker sentiu em torno da sua pessoa um ambiente irrespirável. [...] Partiu para Viena, para Berlim e Budapeste. Nesta última cidade, houve uma reação contra a triunfadora. Acharam que as suas vestimentas eram demasiado ligeiras. Falaram em moral, em perversão dos costumes e outros termos que se vão tornando arcaicos. ${ }^{2}$

Como se percebe, nem tudo eram rosas para Baker e os espinhos não tardaram a aparecer no seu caminho. Dotada de um estilo arrojado, ela usava poucas roupas no palco, não mantinha uma postura de passividade diante dos homens e explorava a sensualidade de seu corpo, o que gerava críticas e protestos. Mesmo assim, a reportagem do jornal Progresso preferiu produzir uma representação enaltecedora da "Vênus negra", assinalando que seu êxito não se restringiu a França. Quando o show da turnê chegou à Áustria, o Secretário de Estado deste país, "Sr. Issekut, beijou a mão negra de Josephine, ao fim da exibição privada, e a dançarina teve amplíssima liberdade para deliciar a estesia dos austríacos". Para finalizar, a reportagem ressaltava que o "sorriso" daquela artista 
afro-americana corria o mundo em fotografias e filmes, afirmando a "vitória da raça preterida no próprio seio do Ocidente". 3

O jornal Progresso tinha razão em algo: Josephine Baker era um dos símbolos do modernismo artístico-cultural. ${ }^{4}$ Sua ascensão no mundo do show business foi meteórica e despertou a atenção dos mais diversos segmentos da sociedade, na Europa, nos Estados Unidos e também no Brasil, onde foi aclamada pela imprensa negra. Por ocasião de sua visita ao país no final da década de 1920, uma série de reportagens, matérias e artigos foi publicada pelo Progresso e, em escala bem menor, pelo O Clarim da Alvorada. Qual a imagem de Baker que foi apropriada e veiculada por esses jornais? É verdade que eles traçaram uma representação enaltecedora da "Vênus Negra", porém, como se configurava essa representação, em termos de discursos e imagens?

A finalidade deste artigo é discutir aspectos da modernidade negra no Brasil e, centralmente, demonstrar que, embora Baker tenha sido escolhida pela imprensa dos "homens de cor" para figurar no panteão dos ícones afro-atlânticos, sua imagem foi apropriada seletivamente. Reforçou-se a faceta de mulher talentosa, famosa e rica - o que constituía uma fonte de orgulho e referência positiva para a "raça" -, e negligenciou-se ou simplesmente esqueceu-se a faceta de mulher controvertida, polêmica, que colocava em xeque aspectos da moral e dos bons costumes da Belle Époque.

\section{De Saint Louis para o mundo}

Antes, porém, de analisar de que maneira Baker foi retratada pela imprensa negra de São Paulo, convém apresentar algumas notas biográficas dessa artista. Frida Josephine McDonald, mais conhecida como Josephine Baker, nasceu em 1906, em Saint Louis, no estado de Missouri, filha de Carrie Mcdonald - uma afro-americana de ascendência indígena e africana - e de Eddie Carson, um músico negro. Sua mãe ganhava a vida lavando roupa e teve mais três filhos de outro relacionamento. Baker passou a infância num ambiente de penúria. Depois de oito meses trabalhando como garçonete no Old Chauffeur's $C l u b$ - um ponto de encontro de músicos de jazz em Pine Street -, anunciou, aos 13 anos de idade, que ia se casar com Willie Weels. O casamento, no entanto, durou pouco tempo.

Baker voltou a ser garçonete e, quando surgiu uma oportunidade, juntou-se a um grupo de artistas mambembes, e deixou St. Louis para tentar melhorar de vida. Foi camareira dos Dixie Steppers e, com essa trupe do circuito negro de teatro de variedades, percorreu o Sul do país, chegando, depois, até Filadélfia, no Norte. Aí, aos 15 anos, casou-se pela segunda vez, com um rapaz cha- 
mado Willie Baker. Não obstante, o segundo casamento durou pouco mais do que o primeiro.

Baker continuou buscando o sucesso. Em 1921, estava se apresentando no Gibson Theater na Filadélfia, com os Dixie Steppers. Conseguira chegar ao conjunto de coristas, substituindo uma bailarina que se machucara. Baker aprendeu a dançar nas ruas, casas e quintais da sua cidade natal. Adolescente, acumulava um enorme repertório de movimentos. Mesmo assim, não foi fácil se afirmar no teatro de variedades. Os Dixie Steppers foram à falência em Filadélfia e a adolescente prodígio pegou o dinheiro que tinha e partiu para Nova York, com o objetivo de atuar no Shuffle Along, grupo que, na época, era o grande empreendimento do teatro negro.

Quando chegou à cidade, dormiu em bancos de praças públicas algumas noites até fazer um teste e conseguir uma vaga na companhia, a princípio, como coadjuvante. Com o término do Shuffle Along, em 1924, Baker entrou no show do grupo The Chocolate Dandies. A essa altura já começava a se destacar e recebia um dos maiores salários da companhia. Depois que The Chocolate Dandies encerrou suas atividades, foi para o Plantation Club, uma boate que apresentava revistas negras, na esquina da Broadway. Foi lá que ela foi contratada para dançar no espetáculo de La Révue Nègre, na França. Nessa ocasião, começava a se tornar famosa por sua capacidade de fazer movimentos mirabolantes com o corpo e, simultaneamente, manter os olhos vesgos. No dia 15 de setembro de 1925, 24 negros - músicos, cantores e bailarinas - embarcaram num navio para fazer a travessia do Atlântico, chegando à França uma semana depois. ${ }^{5}$

$\mathrm{O}$ jornal da imprensa afro-brasileira $O$ Clarim da Alvorada referia-se à França, naquele momento, como "a grande nação amiga da raça negra". ${ }^{6} \mathrm{E}$ não era para menos. Se comparada aos Estados Unidos, a França abrigava um sistema racial mais plástico e maleável. Um episódio relatado pelo jornal é bem sintomático disso. No início de 1930, o príncipe Kojo Tovaion Honéno e seu irmão ambos membros da família real de Daomé, na África -, foram enxotados do Café El Garrón, em Paris, pelo fato de serem negros. Como Paris era "conhecido sempre por sua indulgência a homens e mulheres de todas as raças, nações e cores", aquela discriminação gerou polêmica. Para compreendê-la melhor, cumpre inseri-la no contexto do pós-Primeira Grande Guerra (1914-1918), quando a capital francesa foi "invadida" por norte-americanos brancos, os quais iniciaram ali um movimento para impedir a entrada de homens e mulheres de cor nos cafés e salões de bailes. Algumas casas dependiam, em maior ou menor grau, da clientela norte-americana, por isso começaram a instituir a "linha de cor", nos moldes existentes nos Estados Unidos. ${ }^{7}$

O príncipe Kojo ficou atônito com a postura discriminatória do Café El Garrón e, ao sair do estabelecimento, chamou a polícia. Esta, por sua vez, sabia que 
esse "incidente" poderia abrir um precedente sério e criar um litígio diplomático, porque a França tinha importantes colônias na África e era comum o país receber a visita de negros de várias partes do continente. Para evitar maiores problemas, o delegado de polícia processou o gerente do café. O processo foi julgado com celeridade e $\mathrm{o}$ "proprietário foi sentenciado a quinze dias de prisão com o trabalho forçado e uma multa de dois mil francos, enquanto o Príncipe recebeu indenizações pessoais". ${ }^{8}$ A despeito desse e de outros incidentes pontuais, a França era considerada "a grande nação amiga da raça negra", na década de 1920.

Chegando à Cidade-Luz, Josephine Baker respirou o ar de maior tolerância racial e, quase que incrédula, não sentiu saudades dos Estados Unidos. Gostava de ver o mundo para além da linha de cor, assim como gostava de enfrentar novos desafios. Os ensaios da nova companhia começaram imediatamente e, após grandes expectativas, La Révue Nègre estreou no teatro de Champs-Élysées, em 2 de outubro de 1925. A jovem sorridente e de olhos esbugalhados explodia no palco com uma energia vulcânica. Mexendo com as emoções e explorando suas habilidades pantomímicas, fazia caretas, contorcia-se, remexia-se e gingava freneticamente, de um lado para o outro. Balançava as nádegas, depois as recolhia e saía andando empertigada, ao som sincopado e pulsante do jazz, do black bottom e do charleston - a mais nova sensação musical do momento (Hobsbawm, 1990). Elétrica e espalhafatosa, notabilizava-se pela espontaneidade, expressividade e alegria contagiante. Baker era, em uma só palavra, instintiva. Ao vê-la em cena, as plateias francesas ficavam em estado de excitação, convictas de que estavam diante de algo novo, inusitado, insólito, porém fascinante e hipnotizador. Muitos dos espectadores, já cansados da mesmice e em busca de formas experimentais e renovações artístico-culturais naqueles frementes anos 20 , projetavam suas fantasias naquela afro-americana, tomavam-na como fonte inspiradora de prazer, de vitalidade, de desprendimento e liberalidade. Liberalidade da rígida disciplina, do tolhedor autocontrole e da monótona e repetitiva rotina.

Josephine Baker achou hilariante todo aquele alvoroço. Lia os recortes de jornais e percebia como a imaginação dos brancos era fértil. Eles achavam que ela vinha da selva, era bruta e primitiva. Evitando que as pessoas confundissem a personagem com a dançarina na vida real, ela ostentava um estilo de vida "civilizado", aprendendo o francês, frequentando festas refinadas e usando vestidos da última tendência da moda. Tudo com muito glamour. Pressentia estar a um passo de novas conquistas. Passada a temporada da La Révue Nègre, Baker tornou-se estrela no Folies-Bergère e resolveu alçar voos mais altos. Em questão de não muito tempo, surgiu a oportunidade de se apresentar fora da França. ${ }^{9}$

No mês de março de 1928, ela partiu para uma turnê pelo mundo que se estendeu por dois anos e meio. Seu grande sorriso de olhos vesgos - sua marca re- 
gistrada - continuou encantando. Vibrante, demonstrava uma grande capacidade de inventar e reinventar tudo à medida que ia dançando. As pessoas que assistiam aos seus espetáculos se dividiam entre aquelas que gostavam com entusiasmo, aquelas que os aprovavam e aquelas que atélhes faziam restrições, sobretudo de caráter etnocêntrico, mas ninguém conseguia ficar indiferente. A performance de Baker no palco gerava êxtase geral. Misto de teatro, dança e música, a linguagem artística de seus espetáculos fundia elementos corporais, visuais e sonoros afro-diaspóricos díspares, mas absolutamente criativos, engenhosos e eletrizantes.

No final da década de 1920, o sucesso da "Vênus Negra" era assombroso. Foram lançados perfumes, brilhantinas, roupas e bonecas com a marca Josephine Baker. Seu cabelo, alisado e grudado à cabeça, tornou-se a "coqueluche" do momento, fazendo a "cabeça" das mulheres. Para obter o penteado, havia um produto chamado Bakerfix. As mulheres, que outrora "protegiam a brancura da pele da vulgaridade do bronzeamento, agora passavam óleo de nogueira no corpo para substituir semanas ao sol" (Rose, 1990: 34).

Nem por isso havia consenso em torno da "Vênus Negra". Mulher ambivalente, complexa e multifacetada, eis a melhor maneira para defini-la. Sem levantar bandeiras políticas ou se engajar no movimento de emancipação feminina, assumia um comportamento vanguardista. Sua biógrafa conta que ela era uma mulher de personalidade forte, extrovertida, dinâmica e desprovida de maiores pudores. Quando sentia atração por um homem, fazia sexo com ele. Especialmente em Paris, onde o sexo parecia não ter limitações, ela participou de festas privés, onde chegou a fazer streaptease e participar de várias aventuras. ${ }^{10}$

Namoradeira, não era fiel aos seus parceiros, nem quando estava apaixonada. "A sua mentalidade", afirma Rose (1990:140), "não respeitava as convenções. Ela foi uma dessas mulheres liberadas da década de 1920 que não se submetiam a antigos códigos de conduta". Muitos de seus escândalos foram parar nas páginas dos jornais. Em função de tudo isso, Baker foi pivô de polêmicas e alvo de contestações. Na sua estada em Viena, a primeira cidade da turnê europeia, grupos de estudantes de direita e setores da Igreja Católica lhe acusaram de ser uma mulher devassa, e que sua presença ali provocava a devassidão em outras pessoas. Ao chegar à capital austríaca, alguns estudantes prometeram protestar, mas um grupo fervoroso de admiradores apareceu na estação ferroviária para recebê-la. E, com a ajuda da polícia, ela dirigiu-se ao hotel, onde os estudantes conservadores fizeram sua manifestação. Estava armada a quizila: para muitas pessoas, Baker era um espírito iluminador, o símbolo do cosmopolitismo artístico-cultural da vez; para outras, ela era a encarnação de Satã ou um demônio de imoralidade.

As forças conservadoras não se conformavam com sua presença e enviaram um requerimento ao Parlamento austríaco no sentido de que se impedisse aquele "espetáculo pornográfico". Os parlamentares debateram exaustivamente 
a presumível "atuação pervertida" da "Vênus Negra" e teceram comentários, em sua maior parte negativos, a respeito de seu corpo e de sua cor. "Mesmo assim", afirma Rose, “o Dr. Jerzabek, líder do Partido Clerical, fez questão de esclarecer que não fazia objeção à sua cor, mas sim à sua nudez. Ele estava extremamente irritado com os cartazes, que a retratavam usando nada a não ser penas e contas, 'como um selvagem do Congo"' (Rose, 1990:164).

Baker não sucumbiu à pressão e estreou em Viena com brilho e fulgor. Dali continuou na estrada, abrilhantando os palcos da Hungria, Romênia, Itália, Espanha, Alemanha, Dinamarca, Suécia, Noruega, Holanda. Depois visitou a América do Sul: Argentina, Chile, Uruguai e Brasil. Ao todo, apresentou-se em 24 países e em um número muito maior de cidades.

Por que La Rérue Nègre - um espetáculo de música e dança "negras" - foi bem acolhido na França e sua principal estrela, Josephine Baker, fez sucesso quase que instantâneo? O êxito do espetáculo e de sua estrela está relacionado à conjuntura de valorização dos símbolos e artefatos artístico-culturais afro-diaspóricos. Durante o período do pós-Primeira Guerra muita coisa aconteceu na esfera cultural norte-americana. "A América" - escreveu Edmund Wilson, um dos protagonistas daqueles acontecimentos - "parece estar começando a se exprimir em algo que se aproxima de um idioma próprio" (Wilson, 1987:97). Em livro de fragmentos autobiográficos, o crítico literário aponta elementos para pensar como o país, nos anos 1920, foi marcado por um quadro de efervescência cultural - contradições, aventuras, experimentalismos estilísticos e ansiedades diversas (Wilson, 1987).

Foi nesse cenário de efervescência cultural que emergiu nos Estados Unidos um movimento de intelectuais, romancistas, poetas e teatrólogos voltado a discutir o problema racial. Entre os teatrólogos brancos que fizeram experiências com signos e materiais negros, Eugene O'Neill destacou-se com as peças The Emperor Fones, de 1920, e All God's chillun got wings, de 1924. Em 1926, In Abraham's Bosom, de Paul Green, produzido com elenco predominantemente negro, conquistou para o autor o Prêmio Pulitzer. Carl Van Vechten, Victor Calverton, Henry Mencken, Joel Spingarn e outros emprestaram sua arte ao encorajamento dos negros e ao uso de recursos afro-diaspóricos.

Os intelectuais e artistas brancos não foram os únicos a se debruçar sobre o problema racial. Os negros - principalmente do Harlem, em Nova York também entraram em campo e não perderam a oportunidade de escrever a respeito deles próprios. O movimento, batizado de Harlem Renaissance, reunia os romancistas e poetas negros que, imbuídos da idéia de uma comunidade cultural distinta e autêntica, promoveu a valorização das coisas relacionadas à "raça". Conforme ponderam John Hope Franklin e Alfred Moss Jr., esses escritores estavam "dispostos a usar sua arte não somente para contribuírem para o grande corpo da cultura norte-americana como também para melhorarem a cultura e a 
civilização da qual faziam parte" (Franklin \& Moss Jr., 1989:345). Ao lado das letras, a pintura, a música e o teatro constituíram outros meios pelos quais os negros se expressaram.

Naquele período, Nova York assistiu a uma sucessão de revistas musicais negras de envergadura. Em 1923, houve Liza, de Irving Miller. No mesmo ano, entrou em cartaz Running Wild, de Miller e Lyle, assim como The Chocolate Dandies, de Blake e Sissle, um show que tirou Josephine Baker, definitivamente, do anonimato. Já havia nos Estados Unidos, portanto, um circuito de revistas musicais negras, que começava a despontar nos palcos da Broadway, quando Baker apareceu em cena.

Do outro lado do Atlântico, as narrativas, linguagens e conexões estéticas não eram muito diferentes. Tudo que dissesse respeito ao mundo artístico-cultural africano despertava a atenção dos artistas modernistas, especialmente daqueles ligados ao cubismo e ao surrealismo. Na primeira década do século XX, Henri Matisse, André Derain, Maurice de Vlaminck e Pablo Picasso começaram a colecionar objetos tribais da África: máscaras, estatuetas, imagens e ornamentos. Acervos gigantescos foram montados a partir desses objetos e levados a Paris, quando são exibidos em grandes exposições. ${ }^{11} \mathrm{O}$ que esses artistas viam de descomunal nos artefatos africanos? Uma gramática artístico-cultural mais simples, mais primitiva, mais abstrata, mais direta do que o clássico formalismo da arte ocidental. Acima de tudo, os objetos africanos representavam uma "relação mágica com a realidade, que para Picasso era mais profunda e mais significativa do que as relações que o pensamento científico ocidental nos treinara para identificar e reverenciar como a verdade" (Rose, 1990: 63). Assim, a postura de Josephine Baker, com sua dança selvagem, bunda saliente, joelhos dobrados, costas empinadas, parecia uma cópia fiel de um entalhe africano, da arte primitiva.

Aliando-se aos artistas plásticos, poetas, romancistas e dramaturgos como Blaise Cendrars, Guillaume Appolinaire, André Breton, Paul Éluard e Jean Cocteau - também se renderam ao potencial do patrimônio cultural dos africanos e de seus descendentes em diáspora e chegaram a propalar a ideia de que a arte negra era uma das correntes mais inovadoras no mundo da modernidade. Nesse sentido, é plausível pensar que Baker foi celebrada porque conseguia traduzir, com sua arte e originalidade, o ímpeto da própria modernidade. Negra andrógina, híbrida, que parecia ter brotado do "entre-lugar", ela simbolizava a negação de um modelo de arte racionalizável, que poderia ser apreendida de forma metódica e sistemática. Seus movimentos instintivos, suas improvisações, suas indiscrições, sua sinergia com o público, tudo nela era contagiante, envolvente e alucinante. Numa Europa eivada dos signos da modernidade, todos queriam desfrutar da vida intensamente, como se não houvesse amanhã, e Baker transmitia a impressão de que isso era possível. Naquela atmosfera, a sensação era de que as coisas da vida não se 
submetiam à lógica cartesiana, não seguiam um sentido de linearidade, não eram governáveis ou pautadas por um ritmo de cágado. Refratárias ao planejamento e acontecendo numa velocidade desenfreada, as coisas da vida seriam paradoxais, pluridimensionais, multifacetadas, efêmeras, volúveis, uma vez que, quando menos se esperavam, desmanchavam-se no ar.

O fato é que, na Europa, os ritmos musicais dos negros provocavam entusiasmos e rendiam aplausos (Gilroy, 2007: 343). Em entrevista ao representante da agência brasileira de notícias - e publicada no jornal Progresso -, a cantora brasileira Elsie Houston Perret atribuía o seu êxito ao interesse que os "exotismos" e, particularmente, "todos os negrismos" despertavam no Velho Continente naquele instante. "Com um repertório todo acentuadamente regionalista e em grande parte de ritmos africanos", declarava Perret, "era de esperar que suscitasse algum interesse. Os parisienses já se habituaram às músicas negras, mas, sobretudo, às dos negros norte-americanos". ${ }^{12}$ Apesar disso, a valorização de "todos os negrismos" nos palcos europeus tinha seus limites. Para o show business, o corpo negro era fundamentalmente uma essência, um fetiche, uma caricatura, que devia ser explorado pela perspectiva do exótico, do pitoresco e do espetacular. ${ }^{13} \mathrm{O}$ entusiasmo, neste sentido, não era apenas pela arte, mas antes pela raça, pela potencialidade que essa nova mercadoria tinha na emergente indústria cultural. ${ }^{14}$ Apesar dessas limitações, ambiguidades e contradições, os símbolos e artefatos artístico-culturais afro-diaspóricos foram ressignificados pelos escritores e pintores modernistas, entrando em pauta no panorama europeu e adquirindo uma visibilidade sem precedentes na Paris dos anos 20.

Os fluxos e refluxos das ideias modernistas cruzaram o Atlântico e aportaram no Brasil, de modo que a tendência "global" de utilização da temática africana nas artes, nos moldes de Pablo Picasso e Fernand Léger, e de celebração de Josephine Baker e os músicos de jazz, foram deglutidos localmente. Conquanto em menor escala, os artistas brasileiros se interessaram pela cultura das populações afro-diaspóricas, sobretudo na formação da nacionalidade. Este interesse se expressou em textos teóricos - como os publicados pela revista Estética -, na adoção da temática afro-brasileira nas artes - como o quadro $A$ negra, pintado por Tarsila do Amaral, em 1923 (Amaral, 2006), ou o painel Samba e Carnaval que Di Cavalcanti pintaria, em 1929 - ou na literatura, com Ascenso Ferreira, Raul Bopp e os livros Poemas, de 1927, e Novos poemas, de 1929, de Jorge de Lima.

Escritor conectado às vanguardas europeias e ao movimento de redescoberta do Brasil, Jorge de Lima aderiu, nessa fase, à proposta estética modernista. Sua produção poética é interessante porque não só incorpora a temática da cultura afro-brasileira - por meio do "folclore", do regionalismo, da culinária, da língua e da religiosidade de matriz africana -, como ainda revaloriza a representação da mulher negra. São expressão disso os poemas "Essa negra fulô", "Histó- 
ria", "Quichimbi sereia negra", "Ancila negra", "Rei é Oxalá, rainha é Iemanjá”, "Maria Diamba" e "O banho das negras". Este último conta a história de dois meninos brancos que, ao irem passear numa chácara, assistem umas jovens negras tomando banho no rio. "As molecas eram bonitas, ágeis e puras", conta um dos meninos. "Eu estava, apenas, encantado de ver corpos negros, tão diferentes dos brancos, embelezando-se ligeiros, antes de entrar na água. Reparava que aquele banho era diferente do banho de umas parentas, que me deixaram uma vez esperando por elas, na beira do rio". No final do poema, o menino não oculta o seu espanto: "O contraste daqueles corpos pretos e luzidios sobre a areia das margens ou sob a espuma do sabão me impressionou bastante. [...] Achei lindas as negras. Achei-as ágeis, diferentes" (Lima, 1997:92-93).

Como se percebe, o olhar frente ao corpo da mulher negra é de alteridade. A representação é de um corpo "diferente", exótico, pitoresco, porém "lindo". Em consonância com os postulados da arte moderna, tudo o que era visto como mais puro, autêntico e tribal adquiria o estatuto de "lindo". No poema "Zefa lavadeira", essa representação aparece de forma cristalina. "As negras", escreve o poeta, "aparam a espuma grossa, com as mãos em concha, esmagam-na contra os seios pontudos, transportam-na com agilidade de símios, para os sovacos, para os flancos; quando a pasta branca de sabão se despenha pelas coxas, as mãos côncavas esperam a fugidia espuma nas pernas, para conduzi-la aos sexos em que a África parece dormir o sono temeroso de Cam" (Lima, 1997:83).

O poema de Jorge de Lima veicula imagens de mulheres negras belas, seminuas e sensuais, contudo primitivas, animalescas e próximas ao domínio da natureza. Essas narrativas se remetem, quase que inexoravelmente, à imagem de uma África atávica: tribal, selvagem e exótica. Com efeito, a predileção estética do poeta alagoano não era extemporânea para aquele contexto. Os modernistas procuraram reinscrever a contribuição da cultura afro-diaspórica para a formação do país, inclusive, incursionando pelo tema da mulher negra, mas, para tanto, valeram-se do viés do exótico. ${ }^{15}$

A euforia dos modernistas brasileiros pelo exotismo negro implicou na reverência a Josephine Baker. Considerada um mito vivo, a "Cleópatra do Jazz" ou "Rainha de Paris" - epítetos que lhe imputaram no auge da fama -, era uma das mulheres mais cultuadas na segunda metade da década de 1920 (Sevcenko, 1992:279). No quarto número da revista mineira Verde, de Cataguases, há um poema em sua homenagem, escrito pelo escritor argentino Marcos Fingerit. Trata-se de um indício da repercussão da artista nos meios modernistas. Quando veio ao Brasil, a "Cleópatra do Jazz" ficou hospedada na fazenda Santa Teresa do Alto, de Tarsila do Amaral e Oswald de Andrade. Aqui, participou de várias festas e eventos organizados pelos modernistas com o fito de divulgar o que havia de mais cosmopolita na Europa (Boaventura, 1995). Para os modernistas, tais inter- 
câmbios e conexões representavam a entrada do Brasil no circuito internacional de arte e cultura contemporâneas.

\section{Pelas lentes dos "homens de cor"}

Josephine Baker foi apropriada como referência do modernismo não só pelos artistas e intelectuais brancos, como analogamente pelos órgãos da grande imprensa ${ }^{16} \mathrm{e}$ - talvez principalmente - pelos afro-brasileiros que se acantonavam na chamada imprensa negra. Como, porém, operou-se essa apropriação?

Antes de responder a essa questão, faz-se necessário mencionar que a imprensa negra brasileira consistia, nesse momento, no conjunto de jornais produzidos por (e para) negros em São Paulo no período do pós-abolição. Desses jornais - como O Baluarte, de 1903; O Menelik, de 1915; A Liberdade, de 1919; O Kosmos, de 1922; Getulino, de 1923; O Clarim da Alvorada, 1924; Progresso, de 1928 -, dois se destacaram: O Clarim da Alvorada e Progresso. Segundo Miriam Nicolau Ferrara, O Clarim da Alvorada, criado por José Correia Leite e Jayme de Aguiar, "teve duas fases: de 1924 a 1927 e de 1928 a 1932. No primeiro momento guardou o caráter literário, porém com aspectos combativos; no segundo, assumiu o papel reivindicatório e de cunho político" (Ferrara, 1986:55). O Progresso foi fundado quando os negros decidiram lançar uma campanha em prol da construção de uma herma em homenagem a Luís Gama. Dirigido por Lino Guedes e Argentino Celso Wanderley, tinha a pretensão de ser um jornal sofisticado e distintivo, em sintonia com os valores da "boa sociedade" (Elias, 2001).

Mesmo havendo muitas semelhanças entre esses dois periódicos, é difícil definir um padrão único de conteúdo, formato, linha editorial, meios de produção e distribuição. Geralmente, os editoriais eram voltados para a questão racial, sinalizando aos "homens de cor" - como era comum os negros se autodenominarem na época - os caminhos da conscientização e os mecanismos de ascensão social. Nas outras colunas, dava-se voz para os negros expressarem sua visão de mundo, suas formas políticas, culturais, religiosas, de sociabilidade e lazer, além de conclamá-los a terem amor próprio e se unirem na luta contra o "preconceito de cor". Ambos os jornais prezavam por um código moral rigoroso, baseado na censura à falta de decoro, à vadiagem, ao descuido nos trajes, às danças obscenas, à licenciosidade feminina, aos ambientes de vícios e perversões, à vida boêmia e ao desleixo com a instituição familiar. Para vencer na vida, o negro devia ser civilizado e moderno, e por isso era imprescindível trabalhar, zelar por um comportamento puritano, ter uma reputação ilibada, assim como evoluir culturalmente, investindo nas regras de etiqueta, no aprimoramento educacional e no aperfeiçoamento intelectual (Domingues, 2008; Andrews, 1998). 
Foram esses dois órgãos da imprensa negra-O Clarim da Alvorada e Progresso - que registraram aspectos de Josephine Baker, em sua fulminante carreira artística no final da década de 1920 . Ambos os jornais, principalmente o segundo, apresentaram imagens e representações bastante nobilitantes da "Vênus negra", mas o que isso revelava, ou procurava relevar, e o que omitia ou simplesmente escondia? Eis as questões que, doravante, serão tratadas aqui. Reiteradas vezes a imprensa negra narrou como se deu a emergência da artista no show business francês: "a aparição de Josephine Baker, nos palcos da cidade-luz, fez um barulhão danado. Todos queriam ver aquela criatura de chocolate dançar, espernear, desengonçar-se. Se Josephine fosse inteiramente branca talvez não perturbasse tanto o espírito dos seus admiradores...". ${ }^{17}$

É interessante observar como os jornalistas aglutinados em torno da imprensa negra tinham consciência de que o sucesso de Baker devia-se, em certa medida, ao momento de valorização dos signos da "raça" e da cultura afro-diaspórica na França. "Como todos sabem", dizia o jornal Progresso, "Josephine Baker é norte-americana e tem, seguramente, em suas veias, cinquenta por cento de sangue negro. Este fato explica em parte o seu grande sucesso em Paris, onde alguém que não é absolutamente branco ainda causa assombro". ${ }^{18}$

A "Vênus Negra" era festejada pela imprensa dos "homens de cor" por ter conquistado Paris, cidade tida como a mais civilizada, culta e moderna da Belle Époque. Sua projeção, entretanto, rompeu fronteiras geográficas e se espraiou pela Europa. A partir de um telegrama da Agência Americana de Informações, Progresso noticiava que a "famosa dançarina negra Josephine Baker" encontrava-se em Berlim, tendo sido especialmente convidada para "inaugurar um grande salão de baile". Na terra de Guilherme II, a dançarina negra passeava “à tarde pelas ruas de Berlim, num custoso carro, tirado por um avestruz". ${ }^{19}$ Procurando seguir os passos de Baker, a imprensa negra rastreava todas as suas conquistas. Desta feita, ela foi celebrada porque ampliou o raio de alcance de sua majestade. Agora seria a vez da Alemanha se prostrar diante da "Rainha de Paris".

A presença de Baker na "terra de Guilherme II" causou grandes protestos. Vista como inferior, pervertida e prostituta por alguns segmentos da sociedade civil e do Estado, ela foi desqualificada por meio de discursos de políticos de direita, de declarações de grupos conservadores da Igreja e de moções públicas de repúdio. Entrementes, a imprensa negra silenciou-se frente a tudo isso, posto que não era oportuno transmitir informações que desabonassem a imagem da então diva das populações afro-diaspóricas. $\mathrm{O}$ discurso veiculado pela imprensa negra a associava aos signos da modernidade - da cultura "culta", da fama e da riqueza - e pouco abordava, quando não escamoteava, sua faceta transgressora no tocante às tradições e aos bons costumes.

Durante a excursão de Baker pela América do Sul, Progresso trouxe uma matéria de primeira página, informando que "essa nova repercute fundamente 
nos nossos meios teatrais, sendo procurada com interesse a bailarina que introduziu o charleston e o black bottom na Europa, com isso conseguindo monopolizar a atenção de centros tidos por profundamente cultos". ${ }^{20}$ Conquistar a atenção dos "centros tidos por profundamente cultos" seria uma proeza; não obstante, a proeza seria maior porque a autora dessa conquista era uma negra. A matéria informava ainda que Baker "ganhou uma fortuna colossal" para se apresentar na América do Sul. Naquele instante, encontrava-se em Buenos Aires, mostrando a pujança de seu espírito criador e agradando bastante: "A tez de jambo, os romances de amor que tem provocado, o exotismo de suas toilettes, as suas danças garantem o triunfo". A matéria enfatizava que a bailarina "veio custando um milhão de francos, quatrocentos e cinqüenta contos em nossa moeda, ao empresário que a contratou". ${ }^{21}$

Ao lado da fama - uma conquista simbólica - Baker tinha sua imagem associada à conquista material. Não bastava adquirir fama; também se fazia necessário granjear uma “fortuna colossal”. O jornal conferiu grande visibilidade à presença de Baker na Argentina, assinalando que ela estava "fazendo as delícias do teatro ligeiro em Bueno Aires". ${ }^{22}$ Em duas edições ulteriores, Progresso voltava a dar destaque para a visita da "célebre dançarina" na cidade portenha. Sua estreia foi uma verdadeira consagração, "tendo sido ovacionada, longo tempo, por um numeroso público". ${ }^{23} \mathrm{~A}$ imprensa negra glorificava os triunfos de Baker e secundarizava, quando não ignorava, as controvérsias com as quais a "célebre dançarina" se envolvia direta ou indiretamente.

Mesmo quando esteve na Argentina, os proprietários de teatros em que ela se apresentou "preveniram-se em tempo com as autoridades policiais" $24 \mathrm{e}$ proibiram as "danças seminuas". ${ }^{25}$ Os jornais dos "homens de cor" não informavam maiores detalhes da celeuma, mas é possível supor que a proibição de "danças seminuas" ocorreu por razões morais, no sentido de evitar que o espetáculo de Baker, por seu caráter supostamente obsceno, colocasse em risco as tradições e os bons costumes. ${ }^{26} \mathrm{O}$ fato é que os jornais da imprensa negra preferiram dar relevo para o grande êxito de público e curiosidades do espetáculo, o que até exigiu uma segurança reforçada. ${ }^{27} \mathrm{Na}$ Espanha, as manifestações de protestos a Baker partiram da Associação Católica de Pamplona. Segundo o jornal Progresso, essa entidade publicou um documento "em que aponta como ofensiva à moral as exibições da dançarina Josephine Baker, e pede que seja proibida a representação naquela cidade do programa de variedades da famosa estrela negra". ${ }^{28}$ Como se percebe, a imprensa dos "homens de cor" não silenciou completamente em face das polêmicas morais com as quais Baker se deparava. Contudo, não costumava discuti-las, isto é, entrar no mérito da questão.

Em outro artigo, Progresso retomava a celeuma causada pelas apresentações da "Vênus Negra" em Buenos Aires. De título sugestivo - "Uma grande artis- 
ta, cujo valor não pode ser medido por inteligências medíocres" - 0 artigo refutava os críticos de Baker. Cabe destacar, porém, que, no início, o artigo trazia uma informação-chave: "Josephine Baker recebeu em Buenos Aires uma tremenda vaia". Diante deste fato, o jornal passava a especular: "Não sabemos em que ponto de estética e de finura clássica se colocou a população da grande cidade argentina, para assim vaiar a popular estrela. Não sabemos que sentimentos aristocráticos de requinte a celebrada negra perturbou, com os seus passos sensuais, as suas atitudes cínicas". Para além de especular com a opinião pública argentina, o periódico ironizava: "Pode ser que uma multidão de Leonardos da Vinci e de Rafaéis Sanzios tenha comparecido ao teatro, onde Josephine Baker se exibia e tenha se revoltado contra a insolência das suas poses lascivas, dos seus meneios lúbricos. Tudo é possível na terra". Após a ironia, o jornal resolvia se pronunciar seriamente: "Mas é de crer que nada disso tenha acontecido. O que nos parece haver em tudo isso é uma prova dessa grande hipocrisia, que domina a América". Com efeito, para Progresso, a atitude de vaiar a "Vênus Negra" era uma atitude de pura hipocrisia:

Josephine Baker é, positivamente, o símbolo dos dias de hoje. Ela revelou ao mundo uma forma de arte, a mais característica das formas de arte na época atual. Trouxe dos negros, seus avós e seus pais, os passos extraordinários e pitorescos do black bottom. Imediatamente, o mundo, que procurava novas formas de danças, capazes de corresponder ao estado da alma dos homens de hoje, adotou a ginástica da negra fenomenal [...]. Na cidade mais requintada do mundo, ela causa as delícias das multidões exigentes, que têm visto, através da terra, tudo o que a indústria e a inteligência dos homens puderam descobrir. Com a sua nudez de estátua escura, os seus malabarismos entontecedores, ela é uma das rainhas de Paris. Seu nome arrasta multidões.

O jornal questionava os critérios estéticos utilizados pela plateia argentina para vaiar Baker. Decerto eram critérios duvidosos, pois a "Vênus negra" estava acima das críticas. Pudera, já que ela era uma "eleita", a quem o destino reservou a missão de revelar, e mesmo inventar, formas novas de dança, bem como expressões novas de arte. Com sua "extraordinária e pitoresca" herança cultural afro-diaspórica, ela seria o próprio símbolo da modernidade, daquilo que havia de mais vanguardista, em termos de elementos artísticos, naquele momento. A prova cabal disso é que seu talento já tinha sido reconhecido por "multidões exigentes" da "cidade mais requintada do mundo". Baker era a "rainha de Paris", uma "grande artista, cujo valor não pode ser medido por inteligências medíocres". 
Na parte final do artigo, o jornal mostrava de que maneira aquela negra, de "pernas geniais", vinha influenciando o comportamento da juventude no Brasil. Nos salões "mais honestos", as meninas estavam dançando o black bottom, procurando imitar os "prodígios" dos saltos de Baker. Esta seria a "grande mestra" das jovens que cursavam "colégios severos". Seriam seus os passos mais admirados, considerados perfeitos. "E se é assim no Rio e em São Paulo", afirmava o jornal, não "deverá ser diferente em Buenos Aires, cidade que tem um contato mais direto e permanente com a Europa. Muitas das pessoas que viram Josephine Baker, quando chegaram em casa, devem ter ido para diante de um espelho, procurando imitar-lhe os trejeitos loucos. Não achamos difícil que também entre nós Josephine Baker venha a ser vaiada, quando se exibir. A força da hipocrisia é tão considerável, que não há inteligência capaz de medi-la".29

$\mathrm{O}$ jornal informava aspectos interessantes da recepção de Baker no interior da juventude. Verdadeira popstar, a "rainha de Paris" influenciava as "meninas", lançando moda e influenciando comportamentos e estilos. Isso faz pensar como, no mundo da diáspora africana, circulam os símbolos, os referenciais, os comportamentos e as tendências estéticas, culturais e musicais. Embora dispersas em várias partes do mundo, as populações afro-diaspóricas se comunicam, interagem e se enredam num circuito transnacional de referenciais identitários e culturais (Gilroy, 2001). No entanto, Baker teve a capacidade notável de romper com a fronteira da "linha de cor", de modo que o sucesso de sua arte caiu no gosto popular, de negros e brancos, de jovens argentinas e brasileiras. Diante de um sucesso internacional tão fabuloso, só mesmo a "força da hipocrisia" para ser capaz de vaiar a "rainha de Paris" por ocasião de suas apresentações no Brasil.

A chegada de Baker em terra brasilis foi precedida de grandes expectativas por parte da imprensa negra. Poder estar diante de um mito vivo era um sonho alimentado por parte da "população de cor". É verdade que, de passagem para Buenos Aires, a "bailarina" já havia ficado algumas horas no Rio de Janeiro, "onde não houve quem não a achasse encantadora, extraordinariamente encantadora, de uma simplicidade de maneiras, quase absurda numa personalidade de valor e tanta fama". Baker teria ficado com uma boa impressão do Brasil e feito o seguinte comentário: “-O Rio de Janeiro é a capital mais bela que pude observar, e notem que viajei por treze países". E, mudando de assunto, completou: "Meu desejo é visitar uma fazenda em S. Paulo: quero conhecer de perto a cultura de café". ${ }^{30}$ Antes, porém, de realizar esse desejo, ela excursionou pela Argentina e Uruguai.

Em junho de 1929, Baker aportou, finalmente, para uma temporada no Brasil, fazendo sua estreia em um dos "nossos melhores teatros". ${ }^{31}$ Do Rio de Janeiro, ela foi para São Paulo, para novas apresentações de seu espetáculo. Quando estava na véspera de chegar à terra de Piratininga, o jornal O Clarim da 
Alvorada lhe rendeu loas: "Virá aí a famosa Vênus de ébano, a figura mais popular e mais conhecida do mundo de hoje e cuja estadia, em cada terra, se assinala pelo ruidoso interesse que desperta. Aguardemo-la com as suas excentricidades, e com o seu famoso jazz de negros cubano". ${ }^{32}$ O Clarim da Alvorada salientava tanto a fama retumbante da "Vênus de ébano", quanto as suas "excentricidades".

A dançarina continuou sendo objeto das atenções da imprensa negra. Na sua edição de 24 de novembro de 1929, o jornal Progresso divulgava a estreia de Baker em São Paulo. A famosa "estrela" realizaria apenas três espetáculos, encenados no teatro Santana. Com Baker viriam dois cômicos Buonavoglia e Moreno, um "Jazz-Band" de congoleses e, ainda, uma dupla de bailarinos. ${ }^{33}$ Em sua edição de janeiro de 1930, o jornal aludiu ao que ocorrera na estreia de Baker no teatro Santana. Anunciado o espetáculo, o "logradouro" ficou repleto. Do programa constavam, além das danças, diversos números, executados por outros artistas. Ao iniciar o espetáculo e não aparecer a dançarina, o "povo protestou". Afinal, tinha ido ali para assistir às danças que fizeram Paris delirar. $\mathrm{O}$ conjunto musical, "que executava músicas interessantes, tocou o hino nacional, a ver se assim continha os protestos". Em vão; estes recrudesceram. Compreendeu-se então que os protestos vieram à tona por causa da ausência de Baker. Levantou-se 0 pano e esta, finalmente, "apareceu, dançou e foi muito aplaudida". O jornal comemorava que "Josephine não deixou de debutar" nos palcos paulistas. Em vez de ter manifestado a "força da hipocrisia" - como na Argentina -, aqui ela "estreou e foi muito aplaudida". ${ }^{34}$

Embora tenha sido sacralizada por boa parte da imprensa negra, não havia consenso em torno dos significados políticos, culturais e éticos da "Condessa Pepino". ${ }^{35}$ Seu comportamento vanguardista, ocupando o espaço público com altivez, posicionando-se em controvérsias, frequentando a vida noturna e transmitindo a sensação de independência e liberalidade sexual, transgredia os padrões das relações de gênero e de moralidade vigentes. Por isso, alguns segmentos afro-brasileiros não a viam com simpatia. Em uma nota, o jornal Progresso informava que "certos meninos bonitos", ao passar por "uma senhora ou senhorinha negra”, lhes dizia em voz irônica: “- Josephine!...”. Aqui, a metáfora Josephine não era nenhum elogio; pelo contrário, o termo era empregado como sinônimo de mulher vulgar, despudorada e volúvel; a metáfora Josephine, nesse caso, assumia uma conotação negativa. O jornal reagiu energicamente ao "grosseiro procedimento" daqueles "meninos bonitos", fazendo uma reflexão: "Acaso a Condessa Pepino não é uma grande artista? Paris, consagrou-a; escandalizou-se, Viena; a Argentina, irritou-se com a sua arte, o Rio, agradou-se; S. Paulo - a capital artística - aplaudia-a incondicionalmente". Assim, chamar alguém de Josephine "não é desdouro. Não doe. Ao contrário". 36 
Este episódio é interessante porque sugere como a "Condessa Pepino" era popular no meio negro em São Paulo. Seu nome estava na boca do povo, fazia parte das rodas dos jovens, sendo por vezes evocado nos galanteios masculinos. Ao mesmo tempo, o episódio sinaliza para algo mais importante: os diferentes significados que os afro-paulistas conferiram para Josephine Baker. Não havia unanimidade em torno de seu nome. Se os "meninos bonitos" lhe depreciavam, o jornal procurou the atribuir um significado positivo e retratar os seus "feitos" como uma conquista do conjunto das populações afro-diaspóricas. Para tanto, omitia o aspecto moral do comportamento da dançarina negra e, por conseguinte, recusava-se a discutir de que maneira esse comportamento influenciava as jovens afro-paulistas. Isso não quer dizer que os jornalistas desconheciam o comportamento vanguardista de Baker, mas sim que isso não devia ser lembrado ou, no limite, registrado de forma apenas periférica. Independentemente da questão moral, tratava-se de uma estrela, cujo talento fora reconhecido em Paris, Viena, Argentina, Rio de Janeiro e São Paulo. Em vez de símbolo negativo, Baker representava a visibilidade da mulher negra. No lugar de vergonha, ela devia despertar, acima de tudo, orgulho nos negros de todas as partes.

No entanto, essa não era a opinião de Orígenes Lessa. O jornalista paulista, que chegou a colaborar com a imprensa negra, publicou uma crônica no Progresso bastante sugestiva. Intitulada "Pré, Pró e Post-Josephine", a crônica tinha como eixo o diálogo de Fulano e Cicrano sobre a notícia de organização no Rio de Janeiro, em agosto de 1930, de um novo grupo teatral, denominado Companhia de Mulatas Rosadas. Ao ler a notícia no jornal, Fulano teria ficado revoltado, por entender que o grupo expressava o momento "em que o teatro anda aos trambolhões, vilipendiado, desmoralizado definitivamente". E, o pior, o nascimento daquele grupo representava um atentado contra a nobreza de uma causa que já fora abraçada por Luís Gama, José do Patrocínio, André Rebouças e pela própria Mãe Preta. Uma iniciativa dessa natureza era descabida, já que aqui, diferentemente dos Estados Unidos, havia "uma alma só, um coração só, ligando todos os elementos formadores de um povo". Fulano concluiu seu raciocínio com ar de amargura e inconformismo.

Cicrano respondeu que seu interlocutor estava sendo injusto, uma vez que ele não podia imaginar o "tesouro de possibilidades artísticas que há na raça negra". Todos os nossos músicos teriam "sangue africano". As nossas melhores canções seriam "frutos da nostalgia, da ternura, da bondade do preto". Bastava prestar atenção no sentimento que a "arrumadeira sabe dar às modinhas que canta". Bastava pensar na baiana! Pensar no samba, no batuque, no remelexo! Cicrano continuou refutando Fulano, lembrando que "a revista brasileira sempre viveu da mulata, falsificada ou não. Pense em como a Josephine, que nem sequer era brasileira, conseguiu transtornar multidões, alucinar velhos e emproa- 
dos fidalgos puro sangue... E não me venha mais falar em pouca vergonha...”. Cicrano encerrou a sua argumentação com uma provocação a Fulano:

seja bobo.

Olhe: acenda o seu cigarro baiano. Acenda, fume e não

Fulano acendeu. Tirou uma lenta baforada. E explicou:

- Mas dá pena, não dá?

- Pena de quem? Do teatro?

- Das mulatas, meu velho. Se estragando no palco. ${ }^{37}$

A crônica de Orígenes Lessa evocava uma mensagem desconcertante: Josephine Baker e o teatro de revista brasileiro, que explorava a sensualidade das mulatas, constituíam uma indecência moral, cujo corolário seria o aviltamento da mulher negra. Todavia, a mensagem de Lessa não ecoou, ao menos nos órgãos da imprensa dos "homens de cor". Provavelmente para estes, o jornalista paulista padecia de dois problemas: primeiro, teria utilizado da crônica, um gênero híbrido de literatura que se caracteriza por não ter compromisso com a verdade dos fatos. Por essa perspectiva, Lessa não devia ser levado a sério. Segundo, mesmo que o jornalista paulista não tivesse lançado mão de uma narrativa ficcional, ele, ainda assim, era uma pessoa branca, condição que o impossibilitava de compreender o significado especial, para não dizer mítico, que Baker tinha para frações dos afro-brasileiros. A "Condessa Pepino" não era apenas uma mulata seminua; ela significava, antes, um ícone de mulher afrodescendente talentosa, genial, brilhante, que alcançou os píncaros do esplendor e da notoriedade. No limite, ela simbolizava a vitória do conjunto dos descendentes de africanos na diáspora atlântica.

Em virtude de sua reestreia nos palcos de Paris, após sua excursão pela América do Sul, Baker voltou a ser aplaudida pela imprensa negra. "A 'reentrée' de Josephine Baker em Paris", informava o Progresso, "foi um autêntico triunfo. Venceu em toda linha. Vitoriosa da primeira vez, como mera atenção exótica, a pequena de São Luís teve críticas agora que só se dedicam aos grandes artistas". Oscar Duffene e Henri Varna teriam montado o espetáculo, Paris s'amuse, no Cassino, especialmente para o "reaparecimento da criadora do charleston". E o que "ela fez menos foi dançar. Fez a comediante em scktches e cantou com aquela sua voz de criança, uns versos que a fizeram Rainha de Paris mais uma vez". ${ }^{38}$ Para a imprensa negra, a volta apoteótica de Baker ao show business parisiense teria representado a consolidação de seu talento, como artista versátil, polivalente 
e de recursos múltiplos, capaz de atuar não apenas como dançarina, mas também como atriz e cantora. E, como se previa, a "criadora do charleston" não frustrou as expectativas do público e da crítica, consagrando-se como uma grande artista. ${ }^{39}$ Que ninguém tivesse dúvidas: Baker era uma "vitoriosa".

Em junho de 1940, Jayme de Aguiar - antigo dirigente afro-paulista e, como já vimos, um dos fundadores do jornal O Clarim da Alvorada-, escreveu uma carta para Arthur Ramos, o eminente antropólogo alagoano especializado na "cultura negra". Na carta, Aguiar declara seu desejo de estabelecer contato com o "mestre" e, ao mesmo tempo, informa-lhe sobre o mundo intelectual negro em São Paulo. Imaginava que suas informações poderiam servir de subsídios para as pesquisas de Ramos sobre o "passado da nossa raça, dentro do Brasil e do nosso tão evolutivo Estado de São Paulo". Mas o dirigente afro-paulista também sugeria a importância de reflexões sobre o presente: "Não me atrevo, nem por sonho ditar nem citar observações, apenas espero dar ao preclaro mestre alguns informes que consegui há muito tempo e que no meu baú de velho negro curioso e dedicado às coisas nossas guardei com carinho devotado". Concluindo sua "humilde" sugestão, Aguiar dizia: "Penso que as informações que no momento lhe envio mais se prestam para um estudo literário negro; pouco importa, o mestre, por certo, vai aproveitá-las. Ao mestre ilustre, remeto-as, ciente de que serão bem aproveitadas. Quem sabe se mais tarde se fará a 'antologia dos negros modernos'!... É uma ideia". 40

E que ideia a do Jayme de Aguiar! Tomando em retrospectiva, suas palavras soam como um presságio. É verdade que Arthur Ramos aproveitou o material enviado pelo "velho negro curioso" para os seus estudos sobre a questão racial, mas também é verdade que o "preclaro mestre" não investiu em documentar, e mesmo produzir, a "antologia dos negros modernos" (Gomes \& Fagundes, 2007). Talvez porque ele, em seu afã de encontrar as "sobrevivências africanas" no Brasil, nem achasse que Aguiar e o grupo de negros do qual este fazia parte eram modernos. Chegou a hora de rever essa história, redimensionando o papel dos afro-brasileiros - com seu protagonismo, suas agências e narrativas - no curso da produção de novos cânones. Ou, nos termos colocado pelo fundador d'O Clarim da Alvorada, chegou a hora de se fazer a "antologia dos negros modernos" no país.

Antonio Sérgio Alfredo Guimarães define modernidade negra como "o processo de inclusão cultural e simbólica dos negros à sociedade ocidental" como sujeitos civilizados (Guimarães, 2003:42). Caso se aceite a concepção clás- 
sica de modernidade, a definição do sociólogo baiano é até plausível, mas, se for para seguir na esteira de Paul Gilroy, o conceito de modernidade assumida pela crítica cultural, teoria social, história e filosofia precisa ser repensado. Os discursos sobre a modernidade, baseados na tendência eurocêntrica e nos preceitos iluministas, jamais adquiriram um valor absoluto e universal, sendo incapazes de cruzar todas as fronteiras geográficas, étnicas, religiosas, de gênero, nacionalidade e classe. A história e a cultura expressiva da diáspora africana, por exemplo, não foram plenamente contempladas e circunscritas nesses discursos. Em virtude disso, o sociólogo britânico preconiza uma "revisão das condições nas quais os debates sobre a modernidade têm sido elaborados, uma revisão mais completa do que qualquer um de seus participantes acadêmicos pode estar disposto a admitir".

Faz-se mister uma correção à tradição iluminista da modernidade, valendo-se da experiência histórica das populações da diáspora africana. Dimensionar a modernidade de maneira descentrada e indiscutivelmente plural levaria a uma melhor compreensão da história dos negros no Ocidente e das narrativas das "relações alternadas de dominação e subordinação entre os europeus e o resto do mundo". Conforme salienta Gilroy, as formações políticas negras modernas permanecem concomitantemente dentro e fora da cultura ocidental, que tem sido um "padrasto peculiar". Essa relação complexa aponta para a necessidade de "desenvolver uma crítica ao modo pelo qual a modernidade tem sido teorizada e periodizada por seus defensores e críticos mais entusiastas" (Gilroy, 2001:114). As experiências históricas das populações afro-diaspóricas produziram reflexões sobre a modernidade e seus dissabores, constituindo uma presença constante nos embates culturais e políticos de seus descendentes atuais. "Quero trazer para o primeiro plano da discussão", afirma o autor, "elementos dessa sequência alternativa de investigações sobre a política de vida no Ocidente". Em outras palavras, "estou buscando contribuir para certo trabalho intelectual reconstrutivo que, por olhar para a história cultural moderna dos negros no mundo moderno, tem uma grande relação com as idéias sobre o que era e é hoje o Ocidente" (Gilroy, 2001:108).

Longe de ter pretensões tão ambiciosas, este artigo abordou aspectos da história dos afro-brasileiros que a imprensa negra produziu no período do pós-abolição, explorando, especialmente, a relação desses afro-brasileiros com a modernidade transatlântica. De acordo com Antonio Sérgio Guimarães, a imprensa negra brasileira, nas primeiras décadas do século XX, manteve uma postura de "relativo isolamento", mantendo "diálogo apenas com a grande imprensa local". O diálogo com a "vanguarda europeia", diz o autor, foi "travado pela jovem elite intelectual do país (os modernistas), não pelos negros". Estes tiveram 
como objetivo único a "assimilação à cultura nacional" (Guimarães, 2003: 55-56).

A ilação do sociólogo baiano não tem, contudo, respaldo nas fontes históricas. Como foi evidenciado neste artigo e em pesquisas recentes (Butler, 1998: 210-227; Siegel, 2009: 179-205), a imprensa negra não assumiu posturas isolacionistas ou provincianas. Pelo contrário. Cosmopolita e inserida na experiência da diáspora africana, suas páginas serviram de canal aberto de debates e discussões no bojo da modernidade transatlântica. Jayme de Aguiar não foi o único, nem o primeiro, a se referir aos seus contemporâneos como "negros modernos". Os jornais $O$ Clarim da Alvorada, em 1927, e $A$ Voz da Raça, em 1936, já falavam em "negro moderno". ${ }^{41}$ E tão impressionante quanto frações de afro-brasileiros se autorrepresentarem como modernos, é saber que os articulistas da imprensa negra tinham plena noção de que os ventos do modernismo sopravam a favor do legado cultural afro-diaspórico.

Já em 1924, um artigo do jornal Getulino expressava isso de forma emblemática:

Ultimamente está em moda na Europa a arte chamada "Arte negra". Os decoradores têm buscado, entre os motivos artísticos das tribos africanas mais ou menos selvagens, os elementos de arte suficiente para intentar revolucionar o gosto e a moda imperantes. Há até um crítico de arte que afirmou já muito seriamente: “- Para voltar a escultura à sua simplicidade primitiva, deve ela se inspirar nos fetiches e nos ídolos, rudemente talhados dos negros africanos". Em Londres, no seu Coliseu, desenrola-se nestes momentos um espetáculo original, de singular transcendência artística a cargo de atores e atrizes negros, negros autênticos que conquistaram de assalto um dos mais célebres palcos de Londres. É o espetáculo chamado "Negro spirituals", dirigido por miss Edna Thomas no Coliseu, uma mulher branca que está sugestionada com a alma e com a psicologia artística dos negros. ${ }^{42}$

Em artigo publicado no Progresso, a percepção dos afro-brasileiros a respeito do mais novo fenômeno cultural não é menos aguçada:

O negro tem um grande lugar na história da evolução humana, tem-no na arte moderna e tê-lo-á, ainda, nos destinos da humanidade. [...] A arte nova está se inspirando, toda, na raça paciente e maldita. A música moderna é o gemido bárbaro que subia das senzalas anti- 
gas. Rugem, nela, os ventos do Deserto, em arrancos sonoros que têm a elasticidade do salto dos tigres. ${ }^{43}$

Nota-se, portanto, como os articulistas afro-brasileiros tinham consciência de que a cultura da "raça paciente e maldita", outrora (des)classificada no primeiro degrau da escala evolutiva, era naquele instante concebida como avançada e se revestia de importância singular nos "destinos da humanidade". O fato é que o intercâmbio com a "vanguarda europeia" não foi uma exclusividade dos modernistas "brancos" - grupo de indivíduos que Antonio Sérgio Guimarães denomina de "jovem elite intelectual do país". Os "negros modernos" - como bem designou Jayme de Aguiar - estavam conectados ao que havia de mais inovador e sofisticado no mundo artístico-cultural do Ocidente e, aproveitando-se do espaço da imprensa dos "homens de cor", estabeleceram uma interlocução com as vanguardas europeias.

E mesmo reconhecendo que os afro-brasileiros aglutinados em torno da imprensa negra tinham por finalidade assimilar-se à comunidade nacional, deve-se destacar, no entanto, que esse processo se operou de forma negociada, isto é, não implicou no descarte dos referenciais, símbolos e mitos afro-diaspóricos, nem tampouco implicou em abrir mão dos postulados da sociedade moderna. Não foi fortuito, assim, que um dos pontos altos da interlocução dos afro-brasileiros com a "vanguarda europeia" tivesse girado em torno de Josephine Baker, uma verdadeira alegoria do modernismo nos frementes anos 1920.

Aos dezenove anos, essa jovem negra deixou os Estados Unidos para ir morar na França e, de lá, conquistou o mundo atlântico. Para tanto, teve que enfrentar muitas barreiras e colocar em xeque alguns tabus morais. Quando aceitou ser a artista principal da La Rérue Nègre, teve que fazer um quadro denominado "Dança Selvagem". A intenção do diretor era deixar o espetáculo com uma dança negra mais autêntica, mais pura, mais próxima à Mãe África. Baker teria que se vestir de acordo com a ideia que o diretor fazia do traje africano: corpo nu e penas. Mesmo não sendo nenhum exemplo de mulher casta, a artista inicialmente se recusou a dançar com os seios nus, ameaçando até a abandonar o espetáculo. Ela não era dançarina de striptease. Mas na base do diálogo, o diretor conseguiu convencê-la a se apresentar seminua, condição que, segundo a sua biógrafa, "depois que se acostumou, ela levou muito tempo para se vestir de novo" (Rose, 1990: 20).

Não se tem dúvidas. Baker era despojada e parecia se liberar quando dançava, recorrendo a fontes de energia e espontaneidade que, na maioria das pessoas, estão ocultas sob o manto das vergonhas e restrições sociais, mas nada de rótulos simplistas para pensar o seu significado histórico. Mulher complexa e ambivalente, articulou múltiplas facetas. Sua aceitação por parte do público e da 
crítica deve ser creditada ao caldo de cultura no qual a "negrofilia" - como foi chamado o interesse da vanguarda francesa pela cultura negra - expressava um dos sinais da modernidade. A "negrofilia" era vista como sinônimo de um mundo sensual, rítmico, emocional, primitivo, porém belo e autêntico. Ser moderno e, em especial, estar na moda passava por incluir o contato com os exotismos de todos os "negrismos". Mas a aceitação a Baker derivava, na mesma medida, do seu talento pessoal. No tablado do cenário, ela eletrizava no turbilhão de sua dança, permeada de mímicas desenfreadas, de requebros vertiginosos, de movimentos grotescos, de atitudes improvisadas e absolutamente surpreendentes, dançando e cantando as evocações de lendas de sua "raça". O público - embevecido e atordoado - contemplava-a com estupefação de olhos fixos que, pelo efeito químico do clima de excitação, parecia estar diante de uma miragem. Sua fama correu o mundo e diversas representações dela foram elaboradas, para o "bem" ou para o "mal".

Este artigo examinou como se deu a recepção de Josephine Baker no circuito transatlântico. No caso dos afro-brasileiros que se agenciaram em torno da imprensa negra, estes forjaram uma representação positivada da "Rainha de Paris”. Talentosa, famosa, rica e civilizada, eis as imagens que dela procuraram cristalizar. Para além do discurso de virtudes, Baker foi proclamada um ícone da modernidade afro-atlântica. Suas "vitórias", embora sendo de cunho individual, tiveram um significado ímpar para as coletividades da diáspora africana, de modo que a representação que foi construída pela imprensa negra tanto informava sobre a situação real da "população de cor", quanto referenciava os desejos, as expectativas e os sonhos desse segmento populacional. Em síntese, essa representação revelava - ou procurava revelar - os anseios dos afro-brasileiros de progredir na vida, ascender social e culturalmente e ter o seu talento chancelado pela "boa sociedade". 44

Tendo em vista fabricar uma representação tão positivada de Baker, a imprensa negra precisou minimizar, ou simplesmente esconder, contradições, polêmicas e controvérsias. Isto denota o caráter ambíguo dessas publicações. Se fosse para a "Rainha de Paris" ser julgada pelo tribunal moral da imprensa negra, ela provavelmente não seria absolvida. Afinal, essas publicações se caracterizaram por propalar um discurso centrado na moral e nos bons costumes, nos valores familiares e nas relações de gênero tradicionais. A alternativa encontrada foi se apropriar de uma imagem filtrada de Baker: alardeavam-se suas conquistas e pouco se discutiam, quando não se omitiam, suas posturas tidas como transgressoras. Importava salientar o ícone afro-atlântico, cuja faceta exitosa de glórias tocava forte o coração e enchia de orgulho os negros. Já suas outras facetas, só mesmo "inteligências medíocres" ou a "força da hipocrisia" para escarafunchá-las, diria o jornal Progresso. 
1. Vênus é, na mitologia romana, a deusa do amor, da beleza e do erotismo. Corresponde, na mitologia grega, a Afrodite. Vênus era considerada esposa de Vulcano, mas mantinha uma relação adúltera com Marte. Não fazia parte, a princípio, das grandes divindades romanas. Somente a partir do século II a. C., após identificar-se com Afrodite, é que ela assumiu um lugar de honra no panteão latino (Grimal, 1993: 10-11;466).

\section{Progresso, 13/01/1929, p. 2.}

\section{Idem.}

4. Peter Gay argumenta que é mais fácil exemplificar do que conceituar o modernismo. O conceito é tão polissêmico abrangendo o terreno da pintura, escultura, poesia, prosa, dança, música, arquitetura e design, teatro, cinema etc. que dá a impressão não existir um ponto de intersecção. Ele observa que, para se livrar das armadilhas de um conceito vago e difuso, alguns historiadores culturais têm preferido empregar o plural "modernismos". De qualquer modo, segundo Gay, é possível encontrar uma "unidade na diversidade, um único quadro mental estético e um estilo identificável - o estilo modernista". Mais do que um agregado fortuito de protestos de vanguarda, o modernismo teria engendrado uma nova mentalidade (ideias, sentimentos e opiniões), gerando uma nova maneira de ver a cultura e a sociedade. A despeito de todas as diferenças e até mesmo oposições, os modernistas se caracterizariam por dois atributos: "primeiro, o fascínio pela heresia, que impulsionava suas ações a confrontar as sensibilidades convencionais; segundo, o compromisso com um exame cerrado de si mesmos por princípio", isto é, "o gosto pelo puro gesto de insubordinação bem-sucedida contra a autoridade vigente". Portanto, o ponto de intersecção dos modernistas seria a crença de que "muito superior ao conhecido é o desconhecido, melhor do que o comum é o raro e que o experimental é mais atraente do que o rotineiro" (Gay, 2009:17-19).

5. Os dados biográficos de Josephine Baker basearam-se em Rose, 1990).

6. O Clarim da Alvorada, São Paulo, 25/01/1930, p. 4.

7. O jornal O Clarim da Alvorada explicava melhor essa situação: "Os patronos norteamericanos são muitos e ricos [na França] e sua clientela é muito apreciada nos pontos de reuniões noturnas. Os americanos insistem que não estão acostumados a comer, beber, bailar e associar-se com homens e mulheres não brancos na sua pátria norte-americana; que certamente não gastarão seu dinheiro em pontos de reuniões francesas onde eles estão sujeitos a esfregar os cotovelos com quem não é branco". O Clarim da Alvorada, São Paulo, 25/01/1930, p. 4.

\section{Idem.}

9. O sucesso de La Révue Nègre repercutiu internacionalmente e incentivou o surgimento de empreendimentos artísticos similares. No Brasil, a Companhia Negra de Revistas, criada no Rio de Janeiro em 1926 e congregando artistas respeitados como De Chocolat, Bonfiglio de Oliveira, Sebastião Cirino e Pixinguinha, inspirouse diretamente na experiência da sua congênere francesa. A estreia da troupe ocorreu por meio da peça Tudo preto, o que causou grande impressão no meio artístico nacional. A esse respeito, ver Barros (2005) e Gomes (2004).

10. De acordo com Rose, Josephine Baker "fez amor com o garçom do serviço de copa 
do primeiro hotel em que ficou [em Paris], ansiosa por descobrir como os franceses eram na cama. Aparentemente estava disposta a experimentar praticamente qualquer um, e os homens gostavam tanto dela em parte por perceberem que, ao fazer amor com ela, não estavam se envolvendo num dramalhão". Rose igualmente relata que a "Vênus Negra" chegou a arrancar dinheiro dos homens com os quais fazia sexo: "Em Josephine um rígido núcleo de bom senso reconhecia que, por mais ardorosos que fossem os seus admiradores, de certa forma tudo o que queriam era explorá-la, e portanto parecia inteiramente justo que ela fosse também capaz de explorá-los. [...] Uma vez em Paris ela simplesmente arrancou uma nota de mil francos da mão de um desses rapazes, e de um que não era especialmente rico, bem na hora em que ele ia pagar a conta do que haviam bebido. Quando ele aparentou espanto, ela lhe disse que, se queria sair com atrizes, tinha que pagar o preço" (Rose, 1990: 121, 139).

11. Na edição de 24 de março de 1929, p. 4, o jornal Progresso informava que, na "grande Exposição de Servilha", estava sendo construído um pavilhão por conta da Association Pretty Man dos Estados Unidos. Nele seriam "recolhidos todos os objetos de arte que se relacionem com pretos de qualquer parte do mundo".

\section{Progresso, São Paulo, 24/03/1929, p. 1.}

13. Nicolau Sevcenko narra um episódio que evidencia que o negro era tomado pelos modernistas como uma espécie de totem. Em meados da década de 1920, Nancy Cunard - uma exuberante poetisa surrealista - estava profundamente envolvida com arte negra, de modo que mantinha uma enorme coleção de artefatos africanos e acabou se tornando amante de um negro norte-americano, Henry Crowder, pianista de jazz num bar parisiense. O casal vivia em conflitos porque "Nancy exigia que Crowder usasse adereços que o identifi- casse com a cultura negra tribal, e ele insistia que era apenas um cidadão norte-americano. $\mathrm{O}$ caso terminou no dia em que Nancy o esbofeteou em público num cabaré, com seu braço cheio de braceletes 'negros' importados, gritando-lhe no rosto: 'Seja mais africano'!" (Sevcenko, 1992: 281).

14. Uma hipótese, que não pode ser descartada, para explicar o fenômeno Josephine Baker passa por inscrever sua ascensão no quadro da economia sexual de desejo nas fantasias de raça nos anos 1920. De acordo com Robert Young, o pensamento colonialista tendia a naturalizar a repugnância dos homens brancos pelas mulheres negras. Mas a repugnância sempre carrega a marca do desejo, ainda que no plano latente, de modo que os brancos desenvolveram sentimentos ambivalentes: um misto de fascinação e fobia pelas negras, uma atração libidinal compulsiva negada por uma insistência igual na repulsa. O eixo ambivalente de desejo e repugnância do homem branco foi legitimado através de uma "notável dissimulação ideológica, por meio da qual, a despeito da forma como as mulheres pretas foram constituídas objetos sexuais e comprovaram sua capacidade de sedução graças à própria ação que as vitimava, elas foram também ensinadas a ver-se a si próprias como sexualmente sem atrativos" (Young: 2005185). Se o sucesso de Josephine Baker não deve ser explicado, apenas, pelos seus atributos sexuais, tudo indica que seu "corpo negro" alimentava a imaginação dos brancos e mesmo fomentava as fantasias masculinas. Sua ascensão, por essa perspectiva, está de alguma maneira relacionada à economia sexual de desejo nas fantasias de raça.

15. Na avaliação de David Brookshaw, a reabilitação feita pelos modernistas do elemento afro-brasileiro foi simbólica, "essencialmente artística. Eles não estavam interessados na situação adversa da população negra em massa que formava o 
substratum social". O negro foi "explorado como um símbolo de interesse pela vida e pela liberdade artística, que a intelligentsia branca no Brasil, como sua contraparte em outros países ocidentais, exaltava em sua luta contra o intelectualismo de sua própria cultura e contra os valores sociais gerais da burguesia dominante. $\mathrm{Na}$ medida em que o negro tinha um papel no Brasil, era através de seu espólio invisível, o qual não poderia combinar com a estética física e branca do autor" (Brookshaw, 1983:96).

16. A revista Careta foi um dos órgãos da grande imprensa brasileira que repercutiu a notoriedade estonteante da "Rainha de Paris" no show business: "Paris, que ama as excentricidades, está agora delirando, todas as noites, no 'Folies-Bergère', diante de uma Vênus negra. Josephine Baker - a 'étoile noire', porém, merece a simpatia e a admiração de Paris, porque é uma mulher interessante, de feições finas, de corpo perfeito, e que dança e canta com uma graça muito pessoal. E como o negro está em voga desde a invasão do 'jazz' e das danças americanas, Josephine Baker tem feito um sucesso delirante como grande 'vedete' da nova 'révue' do 'Folies-Bergère' - 'La folie du jour"'. Careta, Rio de Janeiro, 04/09/ 1926. Dois anos depois, a revista Fon-Fon noticiava: "Josephine Baker é uma negrinha importada dos Estados Unidos e que se fez bailarina célebre em Paris, ou assim foi consagrada pelos estrangeiros superexcitados que, na Cidade Luz enchem os teatros e derramam ouro pelas mesas dos cabarets. A bailarina negra hoje domina, ganha milhões, tem Paris aos seus pés. Tudo isto ela conseguiu com pouco esforço, transportando apenas para o palco parisiense a dança sensual dos negros americanos, que consiste numa quase desarticulação dos membros, trejeitos sísmicos, o sacudir da carne". Fon-Fon. Rio de Janeiro, 23/06/1928.

17. Progresso, São Paulo, 23/06/1929, p. 1.

18. Idem.
19. Progresso, São Paulo, 12/08/1928, p. 2.

20. Progresso, São Paulo, 28/04/1929, p. 1

\section{Idem.}

22. Progresso, São Paulo, 28/04/1929, p. 2.

23. Progresso. São Paulo, 23/06/1929, p. 3. As "conquistas" de Josephine Baker no cinema também não passaram despercebidas pela imprensa negra. $\mathrm{O}$ jornal $O$ Clarim da Alvorada lembra, em janeiro de 1930, que a "famosa Vênus de ébano, antes de fazer a sua vitoriosa tournée pela América do Sul, serviu de estrela em sua terra natal, no grande filme 'A Sereia dos Trópicos", obtendo "enorme sucesso". $O$ Clarim da Alvorada. São Paulo, 25/01/1930, p. 4. Em sua edição de 30 de novembro de 1930, o jornal Progresso noticiava que a “dançarina de São Luís" fechou contrato para ser a protagonista de mais um filme.

24. Progresso, São Paulo, 28/04/1929, p. 1.

25. Progresso, São Paulo, 23/06/1929, p. 3.

26. Rose relata que, ao chegar à Argentina, Josephine Baker descobriu que provocava tantos alaridos lá quanto na Áustria e na Alemanha: "Mais uma vez, os liberais e os conservadores se desentendiam quanto à questão de sua atuação. Mais uma vez, ela era uma alma perdida, uma femme fatale, um objeto de escândalo, um demônio de imoralidade. $\mathrm{O}$ presidente Hipólito Irigoyen opôs-se à sua presença. Os seus admiradores gritavam 'Abaixo Irigoyen!' antes das suas apresentações" (Rose, 1990: 170).

27. Progresso, São Paulo, 23/06/1929, p. 3.

28. Progresso, São Paulo, 20/04/1930, p. 3.

29. Progresso, São Paulo, 23/06/1929, p. 3.

30. Progresso, São Paulo, 23/06/1929, p. 1.

\section{Idem.}

32. O Clarim da Alvorada, São Paulo, 24/ 11/1929, p. 2. 
33. Progresso, São Paulo, 24/11/1929, p. 5.

34. Progresso, São Paulo, 31/01/1930, p. 1. Baker teria ficado com uma boa impressão do Brasil. Isto talvez tenha contribuído para a sua volta ao país em outras oportunidades. Em 1939, ela foi contratada para fazer apresentações no Cassino Atlântico, no Rio de Janeiro e, no período em que ficou na cidade, visitou uma "macumba", tendo sido acompanhada por Heitor dos Prazeres, Paulo da Portela, entre outros sambistas. A esse respeito, ver $A$ Noite, particularmente a edição na qual o jornal estampou na primeira página a seguinte manchete: "Josephine Baker dançou na macumba!" (cf. A Noite, Rio de Janeiro, 01/07/1939, p. 1).

35. "Condessa Pepino" - corruptela de Condessa Pepito - foi outra maneira como a imprensa negra se referiu a Josephine Baker. O título de nobreza era uma alusão a Pepito Abatino, com quem a dançarina contraiu em Paris uma união não formalizada. Pepito dizia que tinha em Roma uma carreira administrativa próspera e que fazia parte de uma família nobre italiana. Com o tempo, descobriu-se que ele era um impostor: seu verdadeiro nome era Giuseppe Abatino e que trabalhava como gigolô. De acordo com seus desafetos, ele era "conde nada". Muitos acham que esse gigolô usou Baker e tirou dinheiro dela. No entanto, para Rose, ele impulsionou a carreira dela: "Foi seu agente de publicidade em tempo integral e formulou o mito do passado de Josephine que se provou o mais vantajoso. Ele orientou a sua carreira a longo prazo. Organizou as suas questões financeiras. Deu-lhe um lar. Ela o adorava, vivia literalmente grudada a ele [...] e permitiu que ele a transformasse" (Rose, 1990:143-144).

36. Progresso, São Paulo, 31/12/1929, p. 3.

37. Progresso, São Paulo, 20/08/1930, p. 5.

38. Progresso, São Paulo, 12/1930, p. 3. Josephine Baker não foi a primeira artista negra a pisar em Paris na década de 1920. Entretanto, a receptividade efusiva ao seu espetáculo impulsionou a ida para a capital francesa de outros espetáculos do mesmo gênero. Basta dar um exemplo, que foi divulgado pelo jornal Progresso em 31 de agosto de 1929, p. 3: "O empresário norte-americano Lew Leslie levou para o Moulin Rouge a sua companhia composta de 100 artistas negros e da 'Plantation Orchestra', para representar a famosa revista 'Black-bird', que obteve grande sucesso em New York e Philadelphia. Entre as vedetes figuram duas das mais célebres artistas negras: Adelaide Hall e Aida Ward. Uma delas deverá substituir Josephine Baker na admiração de Paris".

39. Para falar da nova fase Josephine Baker, o jornal Progresso publicou uma entrevista na qual Henri Rollan, "um dos maiores atores de comédia do teatro francês, que São Paulo aplaudiu sem reserva numa curta temporada", assim se manifestou: “[Baker] E admirável! Possui um formidável caráter artístico. Educou-se muitíssimo ultimamente. Isso contribuiu para que se tornasse ainda mais completa. Sou um admirador de grande sensibilidade artística. Ela sozinha equivale a uma companhia completa" (cf. Progresso. São Paulo, 30/08/1931, p. 3).

40. Biblioteca Nacional, seção de manuscritos, Coleção Arthur Ramos, 35,21,492, carta de Jayme de Aguiar a Arthur Ramos enviando alguns dados sobre os negros em São Paulo, São Paulo, 20/06/1940. O autor agradece a Flávio Gomes pela indicação desse documento.

41. "A voz da história e os pretos modernos", O Clarim da Alvorada, São Paulo, 13/05/1927, p. 12; A Voz da Raça, São Paulo, 09/1936, p. 2. Ver também $A$ Voz $d a$ Raça, São Paulo, 05/1937, p. 4 e 01/1937, p. 1 e 4 .

42. Getulino, Campinas, 07/09/1924, p. 3. 


\section{Progresso, São Paulo, 15/11/1931, p. 4.}

44. A revista Fon-Fon ventilava a hipótese de que, para se encontrar a "Vênus negra", não precisava ir muito longe: "Nós temos no Rio muitas Josephine Baker anônimas, que lidam com as panelas durante o dia, e que se perdem, à noite, pelos clubes, onde ainda deixam na porta um pedaço do ordenado. Temos receio até de transportar para o papel a história da bailarina negra, porque Josephine terá, fatalmente, rivais que irão a Paris disputar-lhe o cetro..." (cf. Fon-Fon, Rio de Janeiro, 23/06/1928). A opinião da revista Fon-Fon não era compartilhada por

\section{Referências bibliográficas}

AMARAL, Aracy. Blaise Cendrars e os modernistas. In: - Textos do trópico de capricórnio: artigos e ensaios (1980-2005). Volume 1: Modernismo, arte moderna e o compromisso com o lugar. São Paulo: Editora 34, 2006.

ANDREWS, George Reid. Negros e brancos em São Paulo (1888-1988). Bauru: EDUSC, 1998.

América Afro-Latina (1800-2000). São Carlos: EdUFSCar, 2007.

BAUDELAIRE, Charles. As flores do mal. São Paulo: Martin Claret, 2001.

BARROS, Orlando de. Corações de Chocolat: a história da Companhia Negra de Revistas (1926-27). Rio de Janeiro: Livre Expressão, 2005.

BOAVENTURA, Maria Eugenia. O salão e a selva: uma biografia de Oswald de Andrade. São Paulo: Editora da Unicamp, 1995.
Henrique Cunha, um articulista da imprensa negra. Em determinado artigo do jornal $O$ Clarim da Alvorada, ele utilizava Josephine Baker e Little Esther, outra jovem dançarina afro-americana, como parâmetros para se falar do nível cultural das mulheres negras brasileiras. Segundo Cunha, as afro-americanas eram dotadas do "mesmo espírito racial, da mesma alma sentimental do que temos nós", só que, individualmente, elas se diferenciavam, pois "possuem predicados cultos que são adotados por princípios em sua terra, e que nossas irmãs [de cor] ainda não têm, apesar de que já deviam ter..." (cf.. O Clarim da Alvorada, São Paulo, 26/07/1931, p. 3).

BROOKSHAW, David. Raça E cor na literatura brasileira. Porto Alegre: Mercado Aberto, 1983.

BUTLER, Kim D. Freedoms given, freedoms won: afro-brazilians in post-abolition São Paulo and Salvador. New Brunswick, New Jersey: Rutgers University Press, 1998.

CAULFIELD, Sueann. Em defesa da honra: moralidade, modernidade e nação no Rio de Faneiro (1918-1940). Campinas: Unicamp, 2000.

CUNHA, Olívia Maria Gomes da e GOMES, Flávio dos Santos (orgs.). Quasecidadão: histórias e antropologias da pósemancipação no Brasil. Rio de Janeiro: FGV, 2007.

DOMINGUES, Petrônio. $A$ nova abolição. São Paulo: Selo Negro, 2008.

ELIAS, Norbert. $A$ sociedade de corte: investigação sobre a sociologia da realeza e da 
aristocracia de corte. Rio de Janeiro: Jorge Zahar, 2001.

FERRARA, Miram Nicolau. 1986. $A$ imprensa negra paulista (1915-1963). São Paulo: FFLCH/USP (Série Antropologia, 13).

FLORES, Maria Bernardete Ramos. Tecnologia e estética do racismo: ciência e arte na politica da beleza. Chapecó: Argos, 2007.

FRANKLIN, John Hope \& MOSS JR, Alfred A. Da escravidão à liberdade: a história do negro americano. Rio de Janeiro: Nórdica, 1989.

GAY, Peter. Modernismo: o fascínio da heresia - de Baudelaire a Beckett e mais um pouco. São Paulo: Companhia das Letras, 2009.

GIDDENS, Anthony; BECK, Ulrich \& LASCH, Scott. Modernização reflexiva: política, tradição e estética na ordem social moderna. São Paulo: Unesp, 1997.

GILROY, Paul. O Atlântico negro: modernidade e dupla consciência. São Paulo: Editora 34, 2001.

- Entre campos: nações, cultura e o fascínio da raça. São Paulo, Annablume, 2007.

GOMES, Flávio \& FAGUNDES, Ana Maria. Por uma "anthologia dos negros modernos": notas sobre cultura política e memória nas primeiras décadas republicanas. Revista Universidade Rural: Série Ciências Humanas. Seropédica, RJ, vol. 29, n. 2, 2007

GOMES, Tiago de Melo. Um espelho no palco: identidades sociais e massificação da cultura no teatro de revista dos anos 1920. Campinas: Unicamp, 2004.

GRIMAL, Pierre. Dicionário da mitologia grega e romana. $2^{\mathrm{a}}$ ed. Rio de Janeiro: Bertrand Brasil,1993.
GUIMARÃES, Antonio Sérgio Alfredo Guimarães. A modernidade negra. Teoria $\mathcal{E}$ Pesquisa, São Carlos, n. 42-43, 2003.

HALL, Stuart. Da diáspora: identidades e mediações culturais. Belo Horizonte: Ed. UFMG; Brasília: Representação da Unesco no Brasil, 2003.

HOBSBAWM, Eric J. História social do jazz. Rio de Janeiro: Paz e Terra, 1990.

LIMA, Jorge de. Novos poemas; poemas escolhidos; poemas negros. $2^{\mathrm{a}}$ ed. Rio de Janeiro: Lacerda, 1997.

ROSE, Phyllis. A Cleópatra do jazz: Fosephine Baker e seu tempo. Rio de Janeiro: Rocco, 1990.

REIS, Letícia Vidor de Sousa. "O que o rei não viu": música popular e nacionalidade no Rio de Janeiro da Primeira República. Estudos Afro-Asiáticos. Rio de Janeiro, ano 25, n. 2,2003

SIEGEL, Micol. Uneven encounters: making race and nation in Brazil and The United States. Durham, North Carolina: Duke University Press, 2009.

SEVCENKO, Nicolau. 1992. Orfeu extático na metrópole: São Paulo, sociedade e cultura nos frementes anos 20. São Paulo: Companhia das Letras.

WILSON, Edmund. Os anos vinte: extraído dos cadernos e diários. São Paulo: Com

pa- nhia das Letras, 1987.

YOUNG, Robert J. C. Desejo colonial: hibridismo em teoria, cultura e raça. São Paulo: Perspectiva, 2005. 


\section{Resumo}

A proposta deste artigo é examinar aspectos da modernidade negra no Brasil e, sobretudo, demonstrar como Josephine Baker - uma famosa multiartista afro-americana - foi retratada seletivamente pela imprensa dos "homens de cor" nos frementes anos do pós-Abolição.

Palavras-chave: modernidade; afro-americano; diáspora africana; Atlântico negro; pós-Abolição.

\section{Abstract}

The purpose of this article is to examine aspects of black modernity in Brazil and, over all, to demonstrate as Josephine Baker - a famous Afro-American multiartist - was selectively portrayed by the press of the "men of color" in the agitated years of after-Abolition.

Key words: modernity; Afro-American; African diaspora; Black Atlantic; After-Abolition.

\section{Resumé}

La proposition de cet article est d'examiner des aspects de la modernité noire au Brésil et, surtout, demontrer comme Josephine Baker, une fameuse multiartiste afro-américane a été retracée de façon sélective par la presse des "hommes noirs" dans les années post-abolition.

Mots-clés: modernité; afro americain; diaspora africaine; Atlantique Noir; post-Abolition. 